\title{
Synechococcus elongatus as a model of photosynthetic bioreactor for expression of recombinant $\beta$-glucosidases
}

\author{
Raíza Azevedo ${ }^{1}$, Jéssika Lawall Lopes ${ }^{1}$, Manuel Macedo de Souza², Betania Ferraz Quirino³, \\ Letícia Jungmann Cançado ${ }^{3}$ and Luis Fernando Marins ${ }^{1 *}$ (D)
}

\begin{abstract}
Background: The production of glucose from cellulose requires cellulases, which are obtained from decomposing microorganisms such as fungi and bacteria. Among the cellulases, $\beta$-glucosidases convert cellobiose to glucose and have low concentration in commercial cocktails used for the production of second-generation (2G) ethanol. Genetic engineering can be used to produce recombinant $\beta$-glucosidases, and cyanobacteria may be interesting bioreactors. These photosynthetic microorganisms can be cultured using $\mathrm{CO}_{2}$ emitted from the first-generation ethanol (1 $\left.\mathrm{G}\right)$ industry as a carbon source. In addition, vinasse, an effluent of $1 \mathrm{G}$ ethanol production, can be used as a source of nitrogen for cyanobacteria growth. Thus, photosynthetic bioreactors cannot only produce cellulases at a lower cost, but also reduce the environmental impact caused by residues of $1 \mathrm{G}$ ethanol production.

Results: In the present work, we produced a strain of Synechococcus elongatus capable of expressing high levels of a heterologous $\beta$-glucosidase from a microorganism from the Amazonian soil. For this, the pET system was cloned into cyanobacteria genome. This system uses a dedicated T7 RNA polymerase for the expression of the gene of interest under the control of a nickel-inducible promoter. The results showed that the pET system functions efficiently in $S$. elongatus, once nickel induced T7 RNA polymerase expression which, in turn, induced expression of the gene of the microbial $\beta$-glucosidase at high levels when compared with non-induced double transgenic strain. $\beta$-glucosidase activity was more than sevenfold higher in the transformed cyanobacteria than in the wild-type strain.
\end{abstract}

Conclusions: The T7 system promotes high expression levels of the cloned gene in S. elongatus, demonstrating that the arrangement in which an exclusive RNA polymerase is used for transcription of heterologous genes may contribute to high-level gene expression in cyanobacteria. This work was the first to demonstrate the use of cyanobacteria for the production of recombinant $\beta$-glucosidases. This strategy could be an alternative to reduce the release of $1 \mathrm{G}$ ethanol by-products such as $\mathrm{CO}_{2}$ and vinasse, not only contributing to decrease the cost of $\beta$-glucosidase production, but also mitigating the environmental impacts of ethanol industrial plants.

Keywords: Cellulases, Cyanobacteria, pET system, Genetic engineering, Heterologous expression

\footnotetext{
*Correspondence: dqmluf@furg.br

${ }^{1}$ Laboraty of Molecular Biology, Institute of Biological Sciences (ICB),

Federal University of Rio Grande (FURG), Av. Itália, Km 8, Rio Grande, RS

96203-900, Brazil

Full list of author information is available at the end of the article
} 


\section{Background}

Concerns about world energy consumption and the need to reduce the emission of greenhouse gases have accelerated scientific research on new energy sources and/or more efficient use of available feedstocks. Agroindustrial by-products of vegetal origin have great potential for renewable and sustainable energy generation due to their abundance, biodegradability, hydrocarbon content and low-cost/benefit ratio [1]. One such example is sugarcane bagasse, a by-product of sugarcane-based bioethanol industry, with an annual estimated production of $540 \mathrm{Mt}$ [2]. Its approximate composition is cellulose (50\%), hemicellulose (25\%) and lignin (25\%) [3]. Although much of the bagasse produced is burned in the boilers for bioelectricity cogeneration for the industrial facility itself, studies show that the use of lignocellulosic biomass for the production of second-generation (2G) ethanol may present a lower risk and greater profitability for the investors [4]. Integration of $2 \mathrm{G}$ ethanol production into already existing $1 \mathrm{G}$ ethanol biorefineries may be an attractive business [5] because of the possibility of (1) increasing ethanol production by $30 \%$, without the need to expand the sugarcane-planted area; (2) reducing $\mathrm{CO}_{2}$ emissions during the production process when compared to $1 \mathrm{G}$ ethanol, (3) using the existing and consolidated logistics infrastructure for distribution and utilization (the same used for $1 \mathrm{G}$ ethanol production); (4) using by-products and wastewater from the production of $1 \mathrm{G}$ ethanol; and (5) production during the off-season of sugarcane $[6,7]$.

Second-generation (2G) ethanol is produced in four stages: pre-treatment, hydrolysis, fermentation and distillation. In general, the process consists in the removal of lignin and reduction in the degree of cellulose crystallization (pre-treatment) to facilitate the enzymatic hydrolysis by cellulases and $\beta$-glucosidases, which act to convert cellulose into glucose. Subsequently, the glucose generated is fermented into ethanol by yeast [1]. Although $2 \mathrm{G}$ ethanol has a better energy balance than $1 \mathrm{G}$ ethanol and it is environmentally "friendlier", its production is still not economically viable due to the high cost of the pre-treatment and enzymatic hydrolysis steps [8,9].

Cellulose saccharification (hydrolysis) is catalyzed by three types of enzymes: endoglucanases (EC 3.2.1.4), exoglucanases (EC 3.2.1.91) and $\beta$-glucosidases (EC 3.2.1.21). Endoglucanases break the inner bonds of the cellulose, reducing its degree of polymerization and exposing the microfibrils to the action of the exoglucanases at the ends of the chains, thus releasing glucose and cellobiose. The produced cellobiose acts as inhibitor of the endo- and exoglucanases, negatively affecting enzymatic hydrolysis. Therefore, $\beta$-glucosidases have a crucial role in the process. As they convert cellobiose to glucose, they not only make glucose available for yeast fermentation, but also they prevent cellulase inhibition by cellobiose. Although the action of the $\beta$-glucosidases represents the critical point of the enzymatic hydrolysis of the cellulose, its concentration in the currently commercialized enzymatic cocktails is low, increasing the cost of $2 \mathrm{G}$ ethanol production [10]. Finding organisms able to produce large amounts of cellulose deconstruction enzymes has been an obstacle to the generation of $2 \mathrm{G}$ ethanol [11]. Through genetic engineering, it is possible to develop biofactories for the production of recombinant proteins with desirable characteristics. Some genetically modified organisms have been shown to be more efficient in the production of $\beta$-glucosidases than non-transgenic organisms traditionally used in the production of enzymes [10]. For example, a Pichia pastoris strain was genetically engineered for the expression of a novel $\beta$-glucosidase (NpaBGS) isolated from the fungus Neocallimastix patriciarum, which showed better performance than commercial Novozym - $188 \beta$-glucosidase (Novozymes) [11].

Cyanobacteria are considered attractive hosts for the production of recombinant proteins due to their photosynthetic efficiency (superior to terrestrial plants) [12], cosmopolitan distribution, minimum growth requirements (basically solar energy, water and $\mathrm{CO}_{2}$ ), short life cycle, easy genetic manipulation and high biomass productivity compared to agricultural crops [13, 14]. Genetic engineering has been widely employed in cyanobacteria for the development of biofactories to produce molecules of commercial interest at a reduced cost. Functional enzymes such as ketoacid decarboxylase from Lactococcus lactis, used to produce isobutyraldehyde and isobutanol [15], isoprene synthase from Pueraria montana, for isoprene generation [16] and larvicidal proteins from Bacillus thuringiensis against the mosquito Aedes aegypti [17] are some examples of such enzymes successfully produced in cyanobacteria.

To improve the yield of biomolecules in cyanobacteria, several vectors for chromosome integration, called SyneBricks, have been described for expression of heterologous genes in Synechococcus elongatus PCC 7942 [18]. One of the proposed expression systems was based on the pET expression system developed for expression of heterologous genes in Escherichia coli [19]. This system consists of an insertion of the bacteriophage T7 RNA polymerase into the cyanobacteria genome under the control of an inducible promoter. T7 RNA polymerase binds with high specificity to the $\mathrm{T} 7$ promoter $\left(\mathrm{P}_{\mathrm{T} 7}\right)$, thus triggering targeted transcription of the heterologous gene cloned downstream of this promoter. With such an expression platform, it is not only possible to increase the production of recombinant proteins, but also to control expression of the gene of interest, yielding the protein only when desired. 
It has been estimated that recombinant protein production in cyanobacteria enables conversion of more than $50 \%$ of atmospheric $\mathrm{CO}_{2}$ into protein biomass [20]. In addition to $\mathrm{CO}_{2}$, other residues of the sugarcanederived $1 \mathrm{G}$ ethanol production can be used as a source of nutrients to further contribute to a sustainable and low-cost production of enzymes used in the $2 \mathrm{G}$ ethanol industry. Vinasse, a nitrogen-rich effluent derived from alcoholic fermentation, can be used in the cultivation of cyanobacteria for biofuel (e.g., biodiesel) production [21]. In this context, this study aimed to transform the cyanobacteria Synechococcus elongatus PCC 7942 into a photosynthetic bioreactor for the production of recombinant $\beta$-glucosidases. Due to the fact that $\mathrm{CO}_{2}$ and vinasse can be used for Synechococcus elongatus biomass production, it is possible to integrate the $1 G$ and $2 G$ ethanol processes as previously suggested by Brasil et al. [5].

\section{Results and discussion}

\section{Construction of $\mathrm{pET}$ expression system and insertion into S. elongatus PCC 7942}

Studier and Moffatt developed a gene expression system based on the use of an exclusive RNA polymerase for the expression of heterologous genes [19]. Known as pET expression system, this protein expression platform was developed by inserting the T7 bacteriophage RNA polymerase gene into the Escherichia coli genome. T7 RNA polymerase is characterized by having highly selective and efficient transcription due to high specific binding to the T7 promoter, which does not occur naturally in the host cell genome. Thus, this platform is widely employed for heterologous protein expression in E. coli. In the present work, we used the pET system for expression of a cellulolytic enzyme in S. elongatus PCC 7942.

Bergmann et al. [22] constructed a metagenomic library to isolate new $\beta$-glucosidases from the microbial community of Amazonian soil. Two prokaryotic genes belonging to the GH3 and GH1 families (AMBGL17 and AMBGL18, respectively) were isolated. Although there is no evidence that AMBGL17 gene codes for a true cellobiase, it has been functionally considered as one because its ORF region codes for a $\beta$-glucosidase belonging to GH3 family. As the enzymatic activity of AMBGL17 has already been biochemically characterized and revealed that this enzyme not only possesses a high enzymatic activity and affinity with the substrate $\left(V_{\max }: 16 \mathrm{mM} \mathrm{s}^{-1}\right.$, $\left.K_{\mathrm{m}}: 0.30 \pm 0.017 \mathrm{mM}, K_{\text {cat }}: 38.57 \mathrm{~s}^{-1}\right)$ but also a higher catalytic efficiency $\left(K_{\text {cat }} / K_{\mathrm{m}}\right)$ than many $\beta$-glucosidases described in the literature $\left(128.56 \mathrm{~s}^{-1} \mathrm{mM}^{-1}\right)$, it was chosen for the present work [22].

For the construction of the pET expression system, two neutral sites (NSI and NSIII) were used for the insertion of genes into the cyanobacterial genome through homologous recombination [23]. The gene encoding T7 RNA polymerase (T7RNAP) was inserted at neutral site 1 (NSI) under control of the $\mathrm{Ni}^{2+}$-inducible $\mathrm{P}_{\text {nrsB }}$ promoter (Fig. 1a). Insertion of the T7RNAP expression cassette into the cyanobacterial genome was confirmed by PCR with the amplification of a 1.4-kb fragment, which corresponds to the distance between the genomic locus Synpcc7942_2499 (flotillin membrane protein; flanking the NSI site) and the spectinomycin resistance gene (aadA gene: aminoglycoside resistance protein AadA) present in the genetic construct (Fig. 1a, c). After confirmation of T7RNAP gene insertion into the cyanobacterial genome, a second transformation was performed with the pHN1_AMBGL17 plasmid (Fig. 1b) for integration of the $\beta$-glucosidase gene (AMBGL17) at neutral site 3 (NSIII). Integration was confirmed by the amplification of a 1.8-kb fragment corresponding to the distance between the genomic locus Synpcc7942_0741 (Phage tail protein I gene) and the chloramphenicol resistance gene (cmlR gene: chloramphenicol resistance protein) present in the second genetic construct (Fig. 1b, c).

The double-transformed colonies called S. elongatus $\mathrm{P}_{\mathrm{T} 7}$ AMBGL17 were confirmed by the amplification of a 1.8-kb DNA fragment consisting of part of the genomic locus Synpcc7942_0741 (Phage tail protein I) and part of the chloramphenicol resistance gene present in the genetic construct (Fig. 1c). Vector choice (integrative or replicative) for genetic manipulation is essential to ensure successful transformation. In this work, we chose to use integrative vectors to guarantee gene stability through recombination, with long-term maintenance of the transgenic lineage, as suggested by Heidorn et al. [24].

\section{Effects of transgenesis and nickel addition on cell growth rates}

As Synechococcus elongatus PCC 7942 may harbor from 1 to 10 genome copies, we cannot guarantee that heterologous genes (T7RNAP and AMBGL17) integrated in all genome copies, being virtually impossible to get a homogeneous expression among different strains. Besides that, those genes can be lost during cell division, even in the presence of a selective agent. Due this fact, we performed a qPCR screening 10 strains of double transgenic cyanobacterium ( $\left.\mathrm{P}_{\mathrm{T} 7} \mathrm{AMBGL17}\right)$ to evaluate the difference of gene expression among them and select the strain that presented the best level of expression to be used in the further experiments (data not shown). No significant statistical differences in growth were observed when wildtype and double transgenic $\left(\mathrm{P}_{\mathrm{T}} \mathrm{AMBGL17}\right)$ strains were compared, indicating that foreign DNA integration did not affect cyanobacteria growth (Fig. 2a). However, addition of $5 \mu \mathrm{M} \mathrm{Ni}^{2+}$ in the latency phase (Lag) had a toxic effect to both transformed and wild-type cells, leading to 


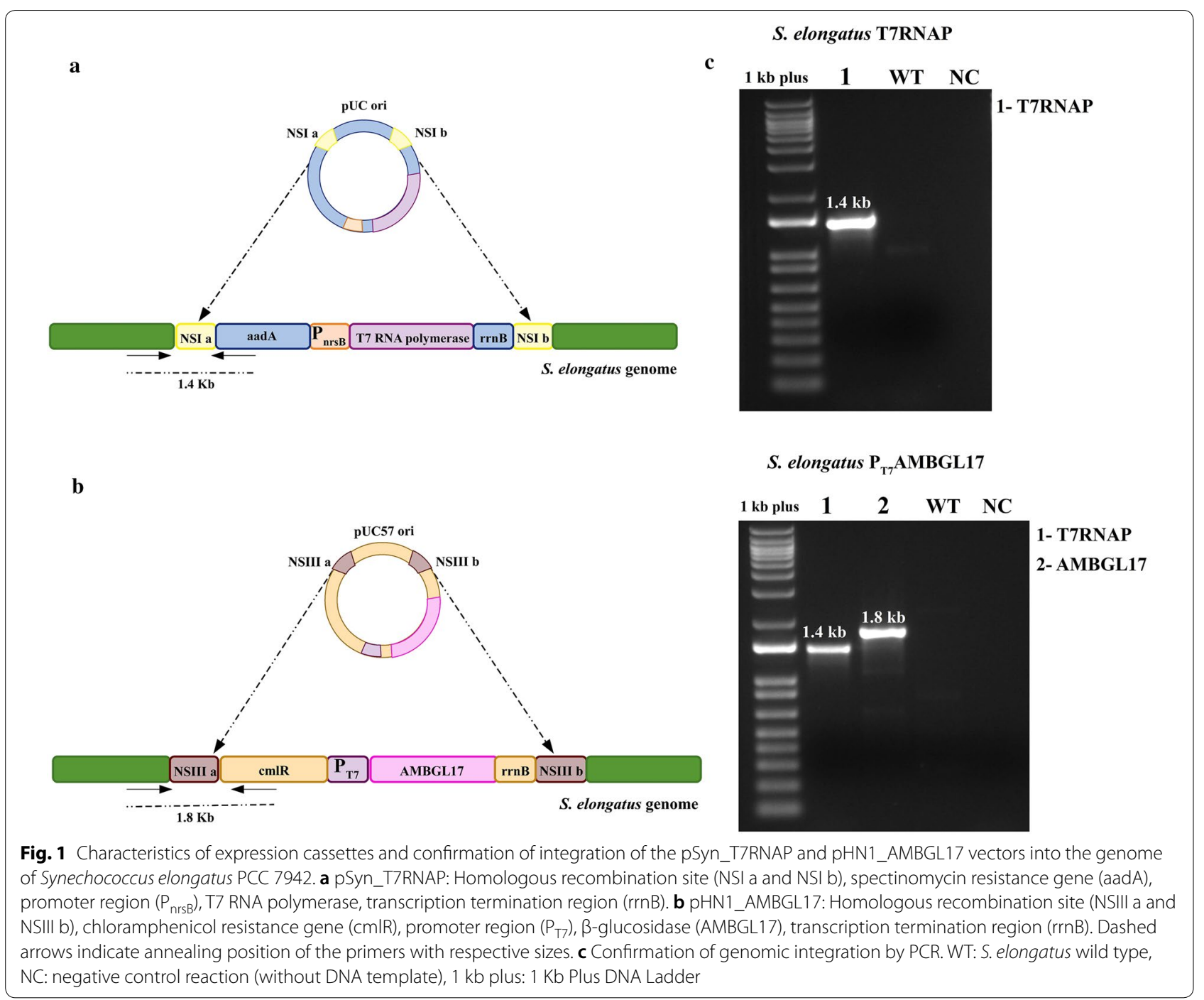

mortality of both strains (Fig. 2a). Lag phase is a period when cyanobacteria adapt to the environmental conditions and is characterized by little or no cell division, but intense metabolic activity [25]. The visible toxic effects that resulted from nickel addition at this stage of cultivation suggest that nickel efflux pumps were not activated, probably causing nickel to accumulate inside the cell, leading to the observed toxic effect. At the stationary phase, when metabolic activity decreases and cell division increases, nickel did not affect cellular viability, demonstrating that the activation of the pET system is not toxic for the wild-type or the double transgenic strains (Fig. 2c). Based on these results, induction at the stationary phase was used in all subsequent experiments.

\section{Determination of expression levels from T7 system}

Induction of expression of the target gene in the pET system is based on the use of the $P_{\text {nrsB }}$ promoter, which is part of the nrsBACD operon, responsible for cyanobacterium resistance to nickel exposure [26]. When present in the cell, nickel "sequesters" the regulatory protein that blocks interaction between the endogenous RNA polymerase and $\mathrm{P}_{\text {nrsB }}$ by modifying its conformation, preventing its blocking activity and thus releasing the promoter region, so that transcription of the T7 RNA polymerase gene can start (Fig. $3 a, b)$. The synthesized T7 RNA polymerase binds to its specific promoter $\left(\mathrm{P}_{\mathrm{T} 7}\right)$ initiating the exclusive transcription of recombinant $\beta$-glucosidase (AMBGL17) (Fig. 3b). Although $\mathrm{P}_{\text {nrsB }}$ is considered a promoter with low non-specific activity, our gene expression data show that in S. elongatus the pET system was activated at basal, even without inducer addition to the culture $(0 \mathrm{~h})$ (Fig. 3c). This was probably due to the presence of divalent metal ions such as $\mathrm{Co}^{2+}, \mathrm{Zn}^{2+}$ and $\mathrm{Cu}^{2+}$ in the BG-11 medium, which are capable of inducing the expression of some 


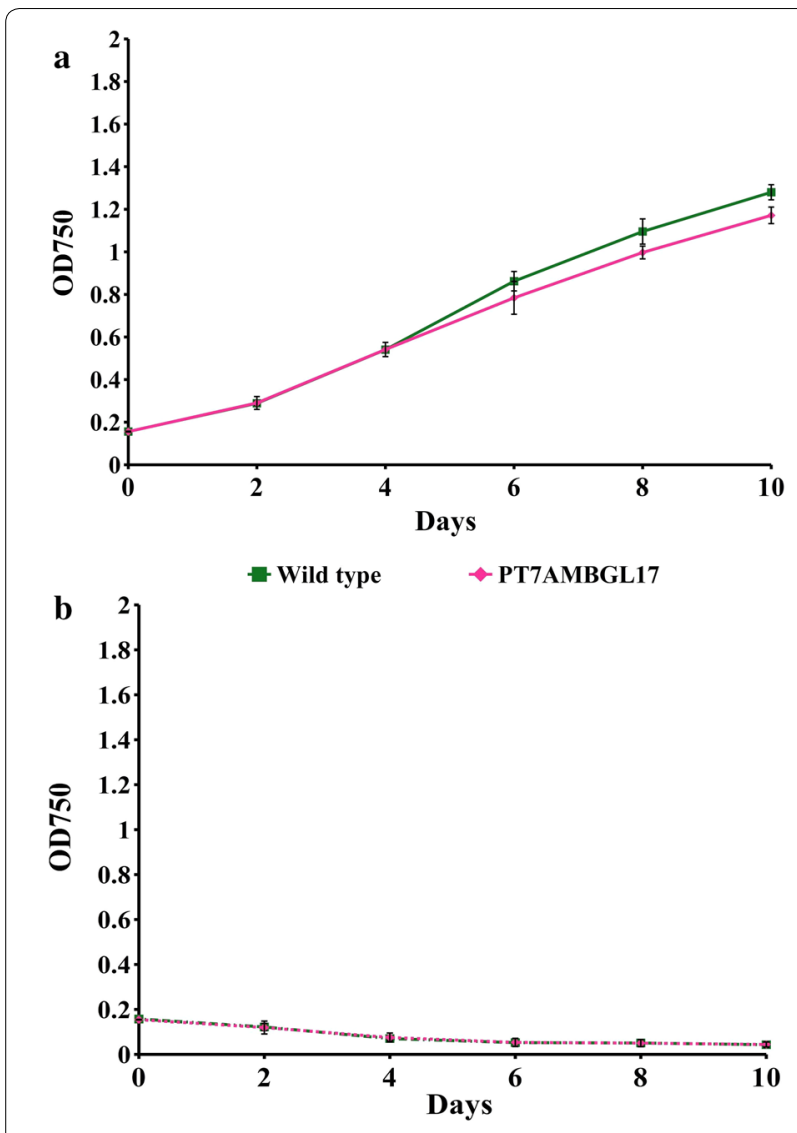

-. Wild type with Ni 2+ ...... PT7AMBGL17 with Ni 2 .

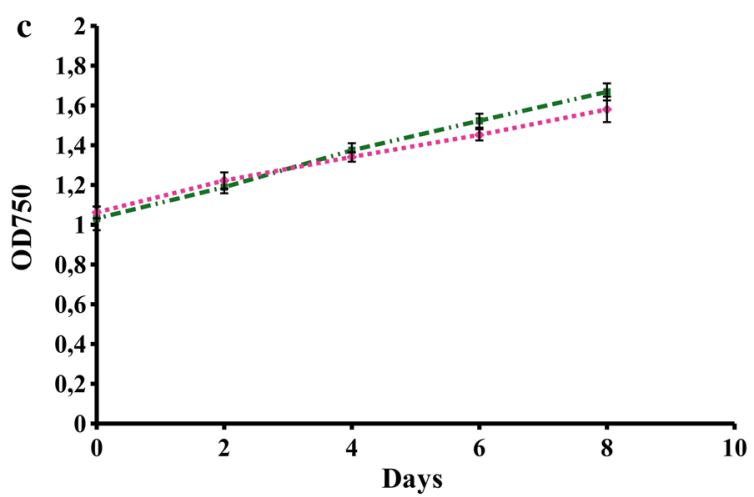

- . Wild type with Ni $2+$

.... ... PT7AMBGL17 with Ni 2+

Fig. 2 Synechococcus elongatus PCC 7942 growth curves. a Effects of genome integration of the two expression cassettes over the transgenic S. elongatus ( $\left.P_{T 7} A M B G L 17\right)$ growth rate in comparison with wild-type growth rate. $\mathbf{b}$ Effects of $5 \mu \mathrm{M}$ nickel $\left(\mathrm{Ni}^{2+}\right)$ addition to $\mathrm{S}$. elongatus wild-type and transformed cultures during the Lag phase. c Effects of $5 \mu \mathrm{M}$ nickel $\left(\mathrm{Ni}^{2+}\right)$ addition to $\mathrm{S}$. elongatus wild-type and transformed cultures during the stationary phase

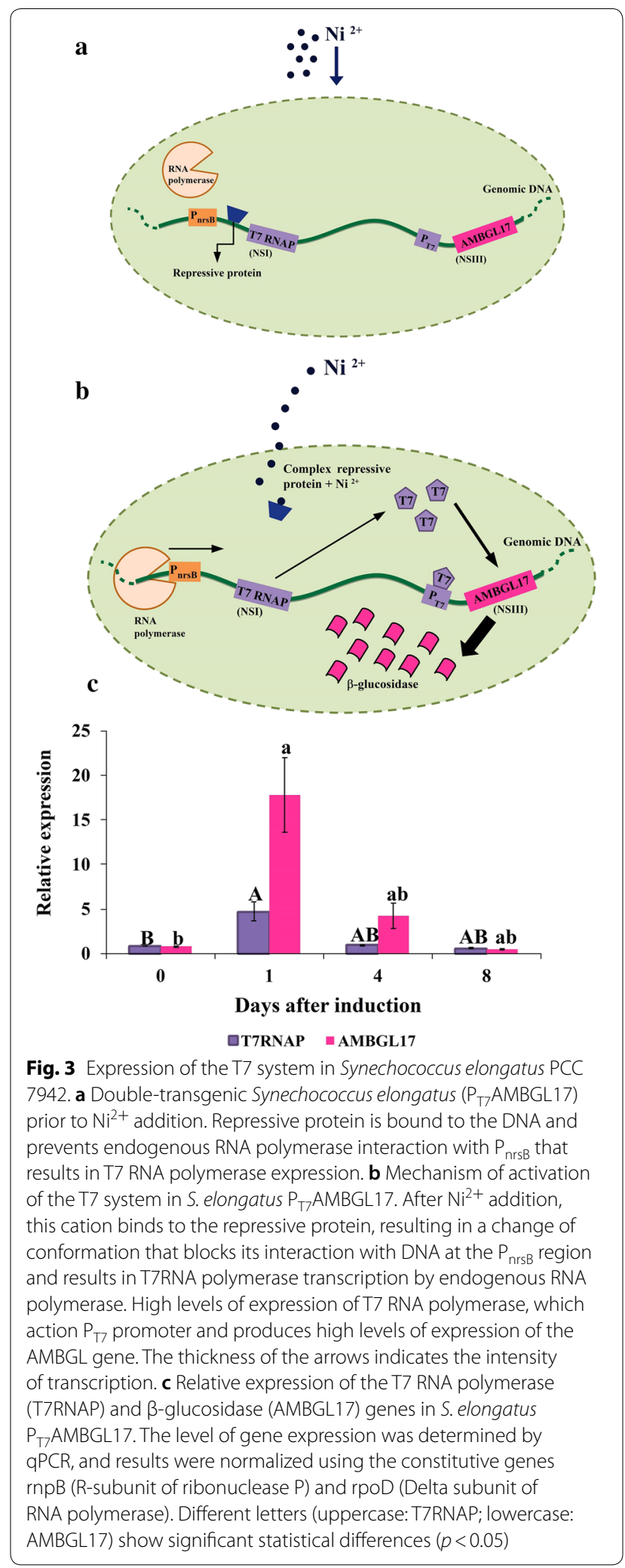


promoters, as previously reported to Synechocystis sp. PCC 6803, another cyanobacterium species [27]. After $24 \mathrm{~h}$ of induction, T7RNAP expression increased approximately 5.5 -fold over the uninduced $(0 \mathrm{~h})$ timepoint, which was sufficient to raise AMBGL17 gene expression by 22 -fold (Fig. 3c).

T7 RNA polymerase is known for its high level of transcription and a low error rate, and thus, relatively small amounts of this enzyme activate the system [19]. The use of the pET system allowed strong gene expression of AMBGL17 in S. elongatus PCC 7942, demonstrating that the system is active and efficient. Therefore, in our work, high levels of T7RNAP expression are not required for high expression of the gene of interest, as previously observed [18].

By analyzing the data over the course of days, we observed a decrease in T7RNAP gene expression and, as a consequence, AMBGL17 reaching approximately zero on the eighth day of induction (Fig. 3c). Probably, this occurred because when nickel was added to activate the pET system, the nrsBACD operon was also activated. This operon contains genes encoding proteins that form complex whose function is to pump nickel out of the cell. Therefore, over time, the system was inactivated and AMBGL17 induction stopped.

Englund and Lindberg suggested that one way to prevent the pumping of nickel out of the cell would be to utilize the genes constituting the nrsBACD operon as sites for homologous recombination of the transgene [27]. In this case, the knockout of the nickel efflux system could prolong the expression of the system by potentiating protein production using a lower concentration of the inducer. However, the functionality of the nrsBACD operon remains to be evaluated.

\section{$\beta$-Glucosidase production}

Although most enzyme assays involve cell lysis, tests previously performed in our laboratory (data not shown) have shown that the presence of large amounts of phycocyanin pigment present in cyanobacteria lysate interferes with the reading of the colorimetric compound (para-nitrophenol-pNP). As the substrate $(\mathrm{pNP} \beta \mathrm{G})$ and enzyme product (pNP) are permeable, being able to cross the cell membrane, it was chosen to carry out the enzymatic activity in the culture medium, without lysing the cells.

By measuring $\beta$-glucosidase activity over $24 \mathrm{~h}$, we observed a significant difference between the $S$. elongatus $\mathrm{P}_{\mathrm{T} 7} \mathrm{AMBGL17}$ and wild-type strains (Fig. 4). Three genes coding for potential endogenous $\beta$-glucosidases were identified in the genome of S. elongatus PCC 7942; these genes are located at loci Synpcc7942_0354, Synpcc7942_0854 and Synpcc7942_1574. It is likely that at

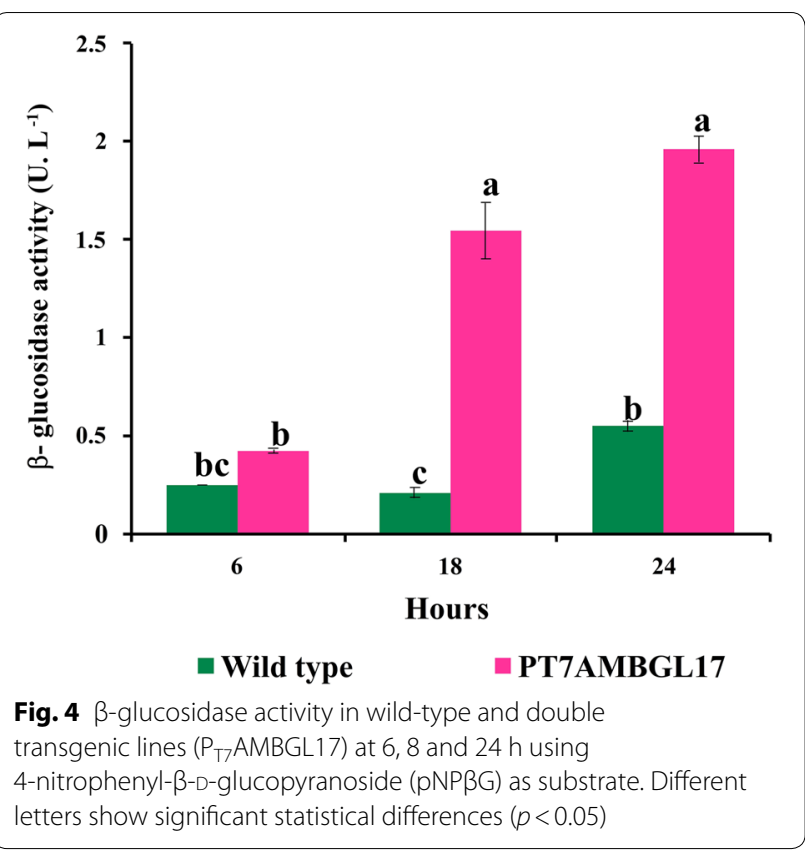

least one of these potential $\beta$-glucosidases is functional, which would explain the activity observed in the wildtype strain.

In the first $6 \mathrm{~h}$ of incubation, $\beta$-glucosidase activity was 1.70 -fold higher in the transgenic strain compared to wild type, with this difference increasing to 7.4 times after $18 \mathrm{~h}$ of incubation, indicating that $\beta$-glucosidase activity in transgenic strain would mostly be performed by the heterologous AMBGL17. However, within $24 \mathrm{~h}$ this difference decreased to 3.5-fold, probably because most of the substrates (pNP $\beta$ G) added to the culture were rapidly consumed by the greater amount of $\beta$-glucosidases produced by the transgenic strain. This did not occur with the wild strain, which has a lower amount of enzymes, thus taking more time to consume the substrate. If more pNP $\beta$ G were added to the culture medium, an increase in activity would probably be observed. Several recombinant $\beta$-glucosidases have been expressed in bacteria and yeasts [28], but there are still no reports of the use of cyanobacteria as a production platform for this enzyme. The present work demonstrated, for the first time, that it is possible to use cyanobacteria as biofactories to produce recombinant $\beta$-glucosidases.

\section{Conclusions}

This is the first work to report an engineered strain of Synechococcus elongatus PCC 7942 able to produce $\beta$-glucosidase from the pET expression system. Our data show that the pET system is active in the cyanobacterium and promotes high expression of the AMBGL17 gene. It has been shown that the use of an exclusive RNA 
polymerase for the transcription of heterologous genes can contribute to high levels of transgene expression in cyanobacteria. This strategy can be further applied to the production of other proteins of commercial value. The use of cyanobacteria as biofactories for the production of $\beta$-glucosidases could enable the use of $\mathrm{CO}_{2}$ and vinasse, effluents of the $1 \mathrm{G}$ ethanol plant, as a source of carbon and nitrogen. This could contribute not only to lower production costs, making ethanol $2 \mathrm{G}$ a competitive product in the market, but also to integrate $2 \mathrm{G}$ production with $1 \mathrm{G}$ already existing biorefineries, mitigating the environmental impacts of bioethanol production from sugarcane.

\section{Materials and methods}

\section{Strains and culture conditions}

Escherichia coli One Shot TOP10 Electrocomp (Invitrogen) was used for cloning and replication of expression vectors. Bacteria were cultured in Luria-Bertani medium [29] supplemented with $100 \mu \mathrm{g} \mathrm{mL}^{-1}$ spectinomycin, at $37{ }^{\circ} \mathrm{C}$, with constant shaking at $250 \mathrm{rpm}$. Synechococcus elongatus PCC 7942 (Thermo Fisher Scientific) was cultured in BG-11 medium [30], at $34^{\circ} \mathrm{C}$, with constant illumination of $8.000 \mathrm{~lx}$. Transgenic cyanobacterial cultures were supplemented with spectinomycin $\left(10 \mu \mathrm{g} \mathrm{mL} L^{-1}\right)$, and expression of the gene of interest was induced with $5 \mu \mathrm{M} \mathrm{NiSO}{ }_{4}$ for $24 \mathrm{~h}$ when the absorbance $(750 \mathrm{~nm})$ of the cultures reached the value of 1 [31]. Optical density (OD) was monitored in a spectrophotometer (BioMate 3, Thermo Scientific).

\section{DNA cloning and vector construction}

Most important elements of all of the expression vectors used in this work are presented in Table 1. For the production of pSyn1_T7RNAP, the T7 RNA polymerase (T7RNAP) gene was isolated from the $E$. coli BL21 (DE3) genome with the primers T7RNAP-FOR/ REV and cloned into pSyn_1 plasmid. The pHN1_ T7AMBGL17 vector was constructed by insertion of the $\beta$-glucosidase gene (AMBGL17; GenBank: KF433952.1) into the pHN1_lacUV5 vector, amplified by PCR using primers AMBGL17-FOR/REV and PNH1-FOR/REV, respectively. PCR products and plasmids were digested with specific restriction enzymes to enable cloning (pSyn_1 and T7RNAP: BamHI and KpnI; pHN1_lacUV5 and AMBGL17: EcoRI and MluI). All enzymes were obtained from New England Biolabs. All DNA fragments were purified (Illustra GFX PCR DNA and gel band purification kit, GE HealthCare) and quantified (Qubit Fluorimeter, Life Technologies), and vectors/inserts were ligated (T7 DNA ligase, New England Biolabs). All procedures were performed following the manufacturer's protocol, and all genetic constructs were sequenced for confirmation of correct cloning. Table 2

Table 1 Expression vectors used in this work

\begin{tabular}{|c|c|c|}
\hline Plasmids & Relevant characteristics & Reference \\
\hline pSyn_1 & pUC, $S p c^{r}$, NSI target sites, $P_{\text {nrs }}$, MCS, rrnB & Invitrogen \\
\hline pHNI_lacUV5 & pUC57, Cmr, NSIII target sites, MCS, rrnB & {$[32]$} \\
\hline pSyn1_T7RNAP & pUC, Spc, NSI target sites, $P_{\text {nrs }}$, T7 RNAP gene, rrnB & This Study \\
\hline pHN1_T7AMBGL17 & pUC57, Cm ${ }^{r}$, NSIII target sites, $P_{T 7}, A M B G L 17$ gene, rrnB & This Study \\
\hline
\end{tabular}

Table 2 Sequence of primers used in this work

\begin{tabular}{|c|c|c|c|}
\hline PRIMERS & Forward primer $\left(5^{\prime}-3^{\prime}\right)$ & Reverse primer $\left(5^{\prime}-3^{\prime}\right)$ & Amplicon (bp) \\
\hline \multicolumn{4}{|l|}{ PCR } \\
\hline T7RNAP & GGATCCGGAAGAGGCACTAAATGAACACG & CCAGGTACCGGAGTCGTATTGATTTGGCG & 2697 \\
\hline AMBGL17 & CACGAATTCTCGACGCTCTCCCTTATGCGACT & CTGACGCGTTACCGGAAGCAGTGTGACCGTGT & 2686 \\
\hline pHN1 & CATACGCGTAGGCGGTGAAGGGCAATCAGC & GTAGGAATTCAAGGGCACCAATAACT & 3850 \\
\hline \multicolumn{4}{|l|}{ Integration } \\
\hline NSI & TGCTGCGTAACATCGTTGCTGCT & ATGTGATCGGAACCCTGAGCCGT & 1400 \\
\hline NSIII & TGGCAGAAGATCGTAGCGGCTCA & CGGATGAGCATTCATCAGGCGGG & 1850 \\
\hline \multicolumn{4}{|l|}{$\mathrm{qPCR}$} \\
\hline RNPB & GTGAGGAGAGTGCCACAGAA & TAAGCCGGGTTCTGTTCTCT & 272 \\
\hline RPOD & GAGCAAGCAAGTCAGCGATTTG & TGAGCCCGCAACCACGATC & 224 \\
\hline T7RNAP & TTGTCCGGTCGAGGACATCCCTG & CTGATACGGCGAGACTTGCGAGC & 153 \\
\hline AMBGL17 & GAAAGGCGGTGGCTCTGTGGATG & GCGGCAGGATGTCACCTTCGTTT & 104 \\
\hline
\end{tabular}


shows the sequences of primers used, which were designed with Primer Express 3.0 software (Applied Biosystems).

\section{Transformation of S. elongatus}

Transformation of S. elongatus PCC 7942 followed the protocol described in the Gene Art Synechococcus Engineering kit (Invitrogen). Cyanobacterial strain was first transformed with the pSyn_1T7RNAP vector. After the transgenic confirmation, the strain was again transformed with the second plasmid (pHN1_T7AMBGL17). As a control, S. elongatus was also incubated without the expressions vectors. After the transformation process, samples were plated on 1.5\% BG-11 agar supplemented with $10 \mu \mathrm{g} \mathrm{mL} \mathrm{m}^{-1}$ of spectinomycin or $12.5 \mu \mathrm{g} \mathrm{mL}$ chloramphenicol.

\section{Confirmation of genomic integration}

PCR was used to confirm the integration of the pSyn1 T7RNAP and pHN1_T7AMBGL17 vectors into the NSI and NSIII sites of the $S$. elongatus genome, respectively. Samples of S. elongatus were heated to $95{ }^{\circ} \mathrm{C}$ for $5 \mathrm{~min}$, centrifuged briefly and the supernatant used as template for the PCRs. PCRs were performed under the following conditions: $94{ }^{\circ} \mathrm{C}$ for $120 \mathrm{~s}$, followed by 35 cycles of $94{ }^{\circ} \mathrm{C}$ for $30 \mathrm{~s}, 58^{\circ} \mathrm{C}$ for $30 \mathrm{~s}, 72{ }^{\circ} \mathrm{C}$ for $90 \mathrm{~s}$, and a final extension of $72{ }^{\circ} \mathrm{C}$ for $5 \mathrm{~min}$. The primers used are described in Table 2 .

\section{Growth measurement}

Inoculum (1.6\%) of wild-type and double transgenic $\left(\mathrm{P}_{\mathrm{T} 7} \mathrm{AMBGL17}\right)$ S. elongatus cultures were added to erlenmeyers $(125 \mathrm{~mL})$ containing $50 \mathrm{~mL}$ of BG-11 medium. All cultures were carried out following the conditions described in item 4.1. The cultures used to evaluate the effect of the transgene on growth and addition of nickel to Lag phase cultures started from the same optical density $\left(\mathrm{OD}_{750}: 0.156 \pm 0.003\right)$. To evaluate the effect of nickel $\left(\mathrm{Ni}^{2+}\right)$ at the start of the stationary phase, the cultures started from an $\mathrm{OD}_{750}$ of 1.047. Growth was monitored in the spectrophotometer (BioMate 3, Thermo Scientific) for 10 days, and $5 \mu \mathrm{M} \mathrm{NiSO}_{4}$ was added at different stages of cultures $\left(\mathrm{OD}_{750}: 0.156 \pm 0.003\right.$ and $\mathrm{OD}_{750}$ : $1.047 \pm 0.019)$ to induce the pET system and evaluate its effect on growth.

\section{Gene expression analysis}

To evaluate expression of the heterologous genes, six samples were collected on days 0 (non-induced), 1, 4 and 8 after induction with $5 \mu \mathrm{M} \mathrm{NiSO}$. Total RNA was extracted with Trizol (Invitrogen) and treated with DNAse I (Invitrogen). The cDNA synthesis was performed with the High Capacity cDNA Reverse
Transcription kit (Applied Biosystems), and cDNA was quantified using the Qubit fluorimeter (Invitrogen). Gene expression was analyzed by quantitative real-time PCR (qPCR) using Platinum SYBR Green qPCR SuperMix-UDG (Invitrogen). Serial dilutions of cDNA were performed to test the efficiency of all primers. The conditions of qPCRs were $50{ }^{\circ} \mathrm{C}$ for $120 \mathrm{~s}, 95{ }^{\circ} \mathrm{C}$ for $120 \mathrm{~s}$, followed by 40 cycles of $95^{\circ} \mathrm{C}$ for $15 \mathrm{~s}$ and $60^{\circ} \mathrm{C}$ for $30 \mathrm{~s}$. The expression of the target genes was normalized by the constitutive genes rnpB and rpoD [33]. All procedures were performed following the manufacturer's protocol, and the primers used are described on Table 2. Data from qPCR were analyzed by the delta $C_{T}$ method [34].

\section{$\beta$-Glucosidase activity}

$\beta$-Glucosidase activity was determined by using p-nitrophenyl- $\beta$-D-glucopyranoside substrate (pNP $\beta G$ ) as described by Strahsburger et al. [35], who performed in vivo assays of $\beta$-glucosidase activity on strains of Bifidobacterium and Lactobacillus by incubating microorganisms with pNP $\beta$ G. After $24 \mathrm{~h}$ of induction with $5 \mu \mathrm{M}$ $\mathrm{NiSO}_{4}, 1.600 \mu \mathrm{g} \mathrm{mL}^{-1}$ of pNP $\beta$ G was added to wild-type and transgenic $S$. elongatus cultures. Culture samples were collected for the determination of total protein concentration (Qubit Fluorimeter, Life Technologies) and $\beta$-glucosidase activity after 6,18 and $24 \mathrm{~h}$ of the addition of pNP $\beta$ G. Cells were precipitated by centrifugation at $10,000 \mathrm{~g}$ for $5 \mathrm{~min}$. The supernatant $(150 \mu \mathrm{L})$ was transferred to a clear 96-well plate containing $50 \mu \mathrm{L}$ of $0.1 \mathrm{M} \mathrm{Na}_{2} \mathrm{CO}_{3}$. Absorbance was measured at the wavelength of $405 \mathrm{~nm}$ (BioTek ELx800 Microplate Reader). A unit $(\mathrm{U})$ of enzymatic activity is defined as the amount of $\beta$-glucosidase required to release $1 \mu \mathrm{mol}$ of $\mathrm{pNP} \beta \mathrm{G}$ per minute per gram of protein under the assay conditions.

\section{Statistical analysis}

For gene expression analysis, it was used six samples for each treatment. Growth measurement and $\beta$-glucosidase activity were performed in triplicate. One-way ANOVA was used to evaluate expression of T7RNAP and AMBGL17 genes over time. The effect of transgenesis and nickel addition on the growth of S. elongatus PCC 7942 was evaluated by two-way ANOVA with repeated measures (factors: transgenesis and time/nickel and time). The effect of transgenesis on enzymatic activity was analyzed by two-way ANOVA with repeated measures (factors: transgenesis and time). All data were tested for their normality and homoscedasticity using the Shapiro-Wilk and Bartlett tests, respectively. A $p<0.05$ was considered, and all the statistical analyses were performed with R Software [36]. 


\section{Abbreviations}

1G: first generation; $2 \mathrm{G}$ : second generation; $\mathrm{CO}_{2}$ : carbon dioxide; $\mathrm{Mt}$ : millions of tons; NSI: neutral site 1; NSIII: neutral site 3; PCR: polymerase chain reaction; $\mathrm{Ni}^{2+}$ : nickel; T7RNAP: T7 RNA polymerase; AMBGL 17: $\beta$-glucosidase AMBGL17; $\mathrm{Zn}^{2+}$ : zinc; $\mathrm{Cu}^{2+}$ : copper; $\mathrm{Co}^{2+}$ : cobalt; pNPßG: $p$-nitrophenyl- $\beta-$ D-glucopyranoside; $\mathrm{P}_{\mathrm{T} 7}$ : T7 promoter; $\mathrm{P}_{\text {nrs }}$ : nickel-inducible promoter; $\mathrm{NiSO}_{4}$ : nickel sulfate; $\mathrm{Na}_{2} \mathrm{CO}_{3}$ : sodium carbonate; $\mathrm{OD}$ : optical density; qPCR: quantitative real-time $P C R$.

\section{Acknowledgements and funding}

This research was supported by the Coordination for the Improvement of Higher Education Personnel Foundation (CAPES) and National Council for Scientific and Technological Development (CNPq). This study was financed in part by the Coordenação de Aperfeiçoamento de Pessoal de Nível SuperiorBrazil (CAPES)-Finance Code 001. L.F. Marins is a research fellow from CNPq/ Brazil (Proc. number 305928/2015-5).

\section{Authors' contributions}

RA and LFM designed the experiments and analyzed the data. RA and JLL performed the experiments. MMS performed the enzyme activity assays. LFM supervised the project. RA and LFM drafted the manuscript with contributions from MMS, BFQ and LJC. All authors read and approved the final manuscript.

\section{Availability of data and materials}

The datasets used and/or analyzed during the current study are available from the corresponding author on reasonable request.

\section{Ethics approval and consent to participate}

Not applicable.

\section{Consent for publication}

The authors agreed to publish this article.

\section{Competing interests}

The authors declare that they have no competing interests.

\section{Author details}

${ }^{1}$ Laboraty of Molecular Biology, Institute of Biological Sciences (ICB), Federal University of Rio Grande (FURG), Av. Itália, Km 8, Rio Grande, RS 96203-900, Brazil. ${ }^{2}$ Institute of Oceanography (IO), Federal University of Rio Grande (FURG), Av. Itália, Km 8, Rio Grande, RS 96203-900, Brazil. ${ }^{3}$ Embrapa-Agroenergy, Parque Estação Biológica, s/n, Brasília, DF 70770-901, Brazil.

\section{Received: 5 April 2019 Accepted: 18 June 2019}

Published online: 03 July 2019

\section{References}

1. Dalena F, Senatore A, Iulianelli A, Di Paola L, Basile M, Basile A. Ethanol from biomass. Ethanol. 2019. https://doi.org/10.1016/B978-0-12-81145 8-2.00002-X.

2. Zhao Y, Chen M, Zhao Z, Yu S. The antibiotic activity and mechanisms of sugarcane (Saccharum officinarum L.) bagasse extract against food-borne pathogens. Food Chem. 2015;185:112-8. https://doi.org/10.1016/j.foodc hem.2015.03.120.

3. Pandey A, Soccol CR, Nigam P, Soccol VT. Biotechnological potential of agro-industrial residues. I: sugarcane bagasse. Bioresour Technol. 2000;74:69-80. https://doi.org/10.1061/40569\%282001\%29197.

4. Tapia Carpio L, Simone de Souza F. Competition between second-generation ethanol and bioelectricity using the residual biomass of sugarcane: effects of uncertainty on the production mix. Molecules. 2019;24:369. http://www.mdpi.com/1420-3049/24/2/369

5. Brasil BSA, Silva FCP, Siqueira FG. Microalgae biorefineries: the Brazilian scenario in perspective. New Biotechnol. 2017;39:90-8. https://linkinghub .elsevier.com/retrieve/pii/S1871678416322713.

6. Soccol CR, de Souza Vandenberghe LP, Medeiros ABP, Karp SG, Buckeridge $M$, Ramos LP, et al. Bioethanol from lignocelluloses: status and perspectives in Brazil. Bioresour Technol. 2010;101:4820-5. https://doi. org/10.1016/j.biortech.2009.11.067.
7. Michailos SE, Webb C. Biorefinery approach for ethanol production from bagasse. Bioethanol Prod Food Crop. 2019;1:1. https://doi.org/10.1016/ B978-0-12-813766-6.00016-3.

8. Stephen JD, Mabee WE, Saddler JN. Will second-generation ethanol be able to compete with first-generation ethanol? Opportunities for cost reduction. Biofuels Bioprod Biorefining. 2012;6:159-76. https://doi. org/10.1002/bbb.331.

9. Rooni V, Raud M, Kikas T. The freezing pre-treatment of lignocellulosic material: a cheap alternative for Nordic countries. Energy. 2017;139:1-7. https://doi.org/10.1016/j.energy.2017.07.146.

10. Rani V, Mohanram S, Tiwari R, Nain L, Arora A. Beta-glucosidase: key enzyme in determining efficiency of cellulase and biomass hydrolysis. J Bioprocess Biotech. 2014;5:197. https://doi.org/10.4172/2155-9821.10001 97.

11. Khattab SMR, Watanabe T. Bioethanol from sugarcane bagasse: status and perspectives. Bioethanol Prod Food Crop. 2019. https://doi.org/10.1016/ B978-0-12-813766-6/00010-2.

12. Dismukes GC, Carrieri D, Bennette N, Ananyev GM, Posewitz MC. Aquatic phototrophs: efficient alternatives to land-based crops for biofuels. Curr Opin Biotechnol. 2008;19:235-40. https://linkinghub.elsevier.com/retri eve/pii/S0958166908000608.

13. Ducat DC, Way JC, Silver PA. Engineering cyanobacteria to generate high-value products. Trends Biotechnol. 2011;29:95-103. https://doi. org/10.1016/j.tibtech.2010.12.003.

14. Sengupta A, Pakrasi HB, Wangikar PP. Recent advances in synthetic biology of cyanobacteria. Appl Microbiol Biotechnol. 2018;102:5457-71. https://doi.org/10.1007/s00253-018-9046-x.

15. Atsumi S, Higashide W, Liao JC. Direct photosynthetic recycling of carbon dioxide to isobutyraldehyde. Nat Biotechnol. 2009;27:1177-80.

16. Lindberg P, Park S, Melis A. Engineering a platform for photosynthetic isoprene production in cyanobacteria, using Synechocystis as the model organism. Metab Eng. 2010;12:70-9. https://linkinghub.elsevier.com/retri eve/pii/S1096717609000871.

17. Khasdan V, Ben-Dov E, Manasherob R, Boussiba S, Zaritsky A. Mosquito larvicidal activity of transgenic Anabaena PCC 7120 expressing toxin genes from Bacillus thuringiensis subsp. israelensis. FEMS Microbiol Lett. 2003;227:189-95. https://doi.org/10.1016/S0378-1097(03)00679-7.

18. Kim WJ, Lee S-M, Um Y, Sim SJ, Woo HM. Development of SyneBrick Vectors as a synthetic biology platform for gene expression in Synechococcus elongatus PCC 7942. Front Plant Sci. 2017;8:1-9. https://doi.org/10.3389/ fpls.2017.00293/full.

19. Studier FW, Moffatt BA. Use of bacteriophage T7 RNA polymerase to direct selective high-level expression of cloned genes. J Mol Biol. 1986;189:113-30

20. Savakis $\mathrm{P}$, Hellingwerf KJ. Engineering cyanobacteria for direct biofuel production from $\mathrm{CO}_{2}$. Curr Opin Biotechnol. 2015;33:8-14. https://doi. org/10.1016/j.copbio.2014.09.007.

21. Montalvo GEB, Thomaz-Soccol V, Vandenberghe LPS, Carvalho JC, Faulds CB, Bertrand E, et al. Arthrospira maxima OF15 biomass cultivation at laboratory and pilot scale from sugarcane vinasse for potential biological new peptides production. Bioresour Technol. 2019;273:103-13. https:// doi.org/10.1016/j.biortech.2018.10.081.

22. Bergmann JC, Costa OYA, Gladden JM, Singer S, Heins R, D'haeseleer $P$, et al. Discovery of two novel $\beta$-glucosidases from an Amazon soil metagenomic library. FEMS Microbiol Lett. 2014;351:147-55. https://doi. org/10.1111/1574-6968.12332.

23. Clerico EM, Ditty JL, Golden SS. Specialized techniques for sitedirected mutagenesis in cyanobacteria. 2007. p. 155-71. https://doi. org/10.1007/978-1-59745-257-1_11.

24. Heidorn T, Camsund D, Huang H-H, Lindberg P, Oliveira P, Stensjö K, et al. Synthetic biology in Cyanobacteria: engineering and analyzing novel functions thorsten. Methods Enzymol. 2011;497:539-79. https://doi. org/10.1016/B978-0-12-385075-1.00024-X.

25. Coutteau P. Micro-algae. Man Prod use live food Aquac. 361st ed. FAO Fisheries Technical Paper; 1996. p. 7-48.

26. Garcia-Dominguez M, Lopez-Maury L, Florencio FJ, Reyes JC. A Gene Cluster Involved in Metal Homeostasis in the Cyanobacterium Synechocystis sp. Strain PCC 6803. J Bacteriol. 2000;182:1507-14. https://doi. org/10.1128/JB.182.6.1507-1514.2000.

27. Englund E, Liang F, Lindberg P. Evaluation of promoters and ribosome binding sites for biotechnological applications in the unicellular 
cyanobacterium Synechocystis sp. PCC 6803. Sci Rep. 2016;6:36640. https ://doi.org/10.1038/srep36640.

28. Singhania RR, Patel AK, Sukumaran RK, Larroche C, Pandey A. Role and significance of beta-glucosidases in the hydrolysis of cellulose for bioethanol production. Bioresour Technol. 2013;127:500-7. https://doi. org/10.1016/j.biortech.2012.09.012.

29. Sambrook J, Fritsch EF, Maniatis T. Molecular cloning: a laboratory manual. New York: Cold Spring Harb. Lab. Press; 1989. https://doi.org/10.1002/ jobm.19840240107.

30. Rippka R, Deruelles J, Waterbury JB, Herdman M, Stanier RY. Generic assignments, strain histories and properties of pure cultures of cyanobacteria. Microbiology. 1979;111:1-61. https://doi.org/10.1099/00221 287-111-1-1.

31. Blasi B, Peca L, Vass I, Kós PB. Characterization of Stress Responses of Heavy Metal and Metalloid Inducible Promoters in Synechocystis PCC6803. J Microbiol Biotechnol. 2012;22:166-9.

32. Niederholtmeyer H, Wolfstadter BT, Savage DF, Silver PA, Way JC. Engineering cyanobacteria to synthesize and export hydrophilic products.
Appl Environ Microbiol. 2010;76:3462-6. https://doi.org/10.1128/ AEM.00202-10.

33. Pinto F, Pacheco CC, Ferreira D, Moradas-Ferreira P, Tamagnini P. Selection of suitable reference genes for RT-qPCR analyses in cyanobacteria. PLoS ONE. 2012;7:e34983. https://doi.org/10.1371/journal.pone.0034983.

34. Livak KJ, Schmittgen TD. Analysis of relative gene expression data using real-time quantitative PCR and the $2^{-\Delta \Delta C T}$ method. Methods. 2001;25:402-8. https://doi.org/10.1006/meth.2001.1262.

35. Strahsburger E, de Lacey AML, Marotti I, DiGioia D, Biavati B, Dinelli G. In vivo assay to identify bacteria with $\beta$-glucosidase activity. Electron Biotechnol. 2017;30:83-7. https://doi.org/10.1016/j.ejbt.2017.08.010.

36. Team R Core. R: A Language and Environment for Statistical Computing Vienna, Austria. 2018. https://www.r-project.org/.

\section{Publisher's Note}

Springer Nature remains neutral with regard to jurisdictional claims in published maps and institutional affiliations.
Ready to submit your research? Choose BMC and benefit from:

- fast, convenient online submission

- thorough peer review by experienced researchers in your field

- rapid publication on acceptance

- support for research data, including large and complex data types

- gold Open Access which fosters wider collaboration and increased citations

- maximum visibility for your research: over $100 \mathrm{M}$ website views per year

At BMC, research is always in progress.

Learn more biomedcentral.com/submissions 